Portland State University

PDXScholar

Fall 2020

\title{
The Seasonal Effects of Photovoltaic Cells on Sedum Eco Roof Substrate Moisture
}

Brook M. Thompson

Portland State University

Follow this and additional works at: https://pdxscholar.library.pdx.edu/honorstheses

Part of the Civil Engineering Commons, and the Environmental Engineering Commons Let us know how access to this document benefits you.

\section{Recommended Citation}

Thompson, Brook M., "The Seasonal Effects of Photovoltaic Cells on Sedum Eco Roof Substrate Moisture" (2020). University Honors Theses. Paper 948.

https://doi.org/10.15760/honors.971

This Thesis is brought to you for free and open access. It has been accepted for inclusion in University Honors Theses by an authorized administrator of PDXScholar. Please contact us if we can make this document more accessible: pdxscholar@pdx.edu. 
The seasonal effects of photovoltaic cells on sedum eco roof substrate moisture

by

\title{
Brook M Thompson
}

An undergraduate honors thesis submitted in partial fulfillment of the

\author{
requirements for the degree of \\ Bachelor of Civil Engineering \\ in \\ University Honors \\ and \\ Civil Engineering
}

Thesis Adviser

Olyssa Starry, Ph.D.

Portland State University

2020 


\section{The seasonal effects of photovoltaic cells on sedum eco roof substrate moisture}

\section{Thompson, B. ${ }^{1}$; Olyssa S. Ph.D. ${ }^{2}$}

${ }^{1}$ Student, Maseeh School of Engineering \& Urban Honors College, Portland State University, USA

$7 \quad{ }^{2}$ Assistant Professor of Urban Ecology, Honors College, Portland State University, Portland, OR, USA

$8 \quad$ Article Info

9 Key Words:

10 Photovoltaic (PV) Cells

11 Microclimate

12 Green roof

13 Ecoroof

14 Combined system

15 Heat flux

16 Optimization

17 Heat Island Effect

\section{Abstract}

This paper investigates a combined PV eco roof system and analyzes the soil moisture levels in

21 front of the panels and directly underneath the PV Cells on an experimental ecoroof platform in

22 Portland, Oregon. The purpose of the study was to examine how PV Cells create differences in

23 the moisture level of the soil on the ecoroof. Four moisture sensors were set in different

24 quadrants in four experimental testbeds, and the moisture level data was recorded from October

$2518^{\text {th }}, 2018$ to September $10^{\text {th }}, 2019$. The study found that in with heavy rainfall, the front of the

26 testbed displayed more moisture, possibly because of the rain shading effect of the panels. In the

27 dry periods, the moisture level behind the panels was higher, possibly because of the shading of

28 the PV cells allowed for the retention of water through slowed evaporation. Combined system

29 green roofs and PV cells deserve more research. Future work should be repeated in multiple 
30 locations with different irrigation systems and plants to determine if these findings are applicable

31 on a larger scale.

\section{$32 \quad \mathbf{1 . 0}$ Introduction}

33 Portland, Oregon, has embraced solar technologies and green roofs, which can be seen from the

34 Ecoroof Standard in the 2035 plan ("Central City 2035 - Ecoroof Standard"). Ecoroofs are a type

35 of green roof that typically needs little maintenance. The policy to have eco-roofs on Portland

36 buildings has been in place since 2011, which requires all city-owned facilities and roof

37 replacements over 500 square feet to have ecoroofs installed ("Case Study: City of Portland,

38 Oregon Ecoroofs Incentive"). Forty percent of the city ecoroofs can have mechanical equipment

39 installed, which includes PV Cells. There are many benefits of having photovoltaic cells in a

40 combined system with green roofs, the main ones being that the green roof cools the PV cells,

41 making them more efficient, and the PV cells provide shading for parts of the green roof

42 (“Central City 2035 - Ecoroof Standard”). This paper will investigate PV cells affect green roof

43 moisture dynamics. How does having a PV system on top of a green roof affect the moisture

44 levels directly behind the panels compared to the front? It is predicted that the PV cells will

45 affect the moisture directly underneath the cells.

47 This research will investigate soil moisture in combined systems, but it is also crucial to

\subsection{Advantages and Disadvantages of a Combined Solar and Green Roof System} understand why combined systems should be studied and are valuable in urban environments in the first place. This section is dedicated to understanding the pros and cons of combined PVgreen roof systems. 


\subsubsection{Advantages of a Combined System}

52 PV and green roofs have a large benefit of the green roof, cooling the PV cells leading to more

53 energy output. A reduction in the urban heat island effect and the overall benefits that green

54 roofs provide for are additional benefits.

55

56

57

58

59

60

61

62

63

64

65

66

67

68

69

70

71

72

73

\subsubsection{Potential Benefits from the Green Roof}

Green roofs are a large part of the benefit of having a combined system. Hydrological and air quality gains are aspects of green roofs. Popularity for green roofs has risen over the last ten years (Dinardo 2016). Green roofs can retain water during storm events causing a delay of entry to combined stormwater and wastewater systems meaning that wastewater treatment plants will have more time to process fallen rainwater, reducing the system burden. In Portland, rainfall retention in the winter can be $12 \%$ and $42 \%$ in the summer, with extreme retention as low as $0 \%$ in the winter, as high as $85 \%$ in the summer (Spolek 2008). Through the city of Portland's incentives from 2008 to 2011,8 acres of green roofs have managed an average of 3.3 million gallons of stormwater each year ("Case Study: City of Portland, Oregon Ecoroofs Incentive”).

Garrison reasons that a green roof policy should be implemented on the basis that they would be beneficial with their connection with improved air quality (Horowitz et al. 2012). Through transpiration, plants circulate air and pull certain pollutants into their leaves through microscopic openings in a process called stomata. Plants also take carbon dioxide, sunlight, and water to produce oxygen, air, and sucrose. In Yang's article, “Quantifying air pollution removal by green roofs in Chicago," intensive green roofs, including trees, shrubs, and grasses, removed ozone, nitrogen dioxide, and PM10 particulates (Yang et al. 2008). Green roofs have the potential to increase air quality in urban environments and reduce system pressure on combined urban wastewater treatment. 
75 Green roofs can have a positive impact on mitigating the urban heat island effect. The urban heat 76 island effect is when an urban area experiences warmer temperature than the surrounding rural

77 areas. According to the Environmental Protection Agency, "Heat islands can affect communities

78 by increasing summertime peak energy demand, air conditioning costs, air pollution and

79 greenhouse gas emissions, heat-related illness and mortality, and water pollution." ("Heat Island

80 Effect”). Roofs with a combined system could reduce sensible heat flux by $45 \%$ (Scherba et al.

81 2011). Sensible heat flux is the transfer of energy-related to changes in temperatures. Green roofs

82 reducing the heat island effect was also encouraged by the Natural Resources Defense Council's

83 research on reducing climate change in Southern California (Horowitz et al. 2012).

84

\subsubsection{Optimization}

The large benefit of having a PV cell and green roof combined system is that the green roof creates a microclimate that cools the immediate area around the vegetation, which is beneficial to the solar panels since it allows them to run more efficiently, resulting in more power output (“Central City 2035 - Ecoroof Standard”; “Stormwater Management Manual”). In a 2011 Hong Kong study their urban combined system resulted in $8.3 \%$ more electricity than having PV cells alone on a roof (Hui et al. 2011). Butler and Orians found in their 2011 Massachusetts study that their vegetation on their green roof reduced the temperature of the soil by a maximum of $44^{\circ}$ Celsius. Chemisana and Lamnatou found the combined system not only increased the maximum power output of their solar panels but that the PV modulus protected the plants from high irradiances (Chemisana et al. 2014). Overall, having a combined system is a benefit to the PV modules. 


\subsubsection{Potential Disadvantages of a Combined System}

97 Cons of having a combined system include the capital cost associated, application of installing a combined system, and the space required for installation.

\subsubsection{Financial Capital}

100 101

The major con to installing combined system roofs is the cost associated with the initial installation, maintenance, and the environmental cost over the lifetime of the panels. Statler's research paper focused on the costs of combined systems versus separate systems in Portland, OR. A 2014 cost analysis of the ecoroof incentive by the city of Portland found that the median installation costs, "range from approximately $\$ 6.00$ per square foot for single-family residences up to $\$ 15.55$ per square foot for institutional installations." ("Cost Analysis for Portland Ecoroof Incentive"). Statler found that the best return on investment came when older buildings installed green roofs alone, but newly constructed buildings built combined systems (Statler 2017). The ecoroof standard for the city of Portland referenced that, on average, ecoroofs can cost approximately $4 \%$ more to maintain than a standard roof ("Central City 2035 - Ecoroof Standard"). Contrary to this, a typical roof needs replacement every 20 years, while an ecoroof only needs replacement every 40 years, in such a way that these costs may balance out, dependent on the amount of time the building is inhabited ("Central City 2035 - Ecoroof Standard"). In extreme weather events, the plants may die, although sedum are resilient, replacing plants that have died or have been taken over by weeds is an unpredictable maintenance cost [1]. Finally, there may be a cost barrier to lower class residential citizens who wish to utilize the technology. Despite praise for Portland's incentive, citizens can be deterred if they do not fall into a high enough tax bracket to have tax credits be useful. ("Investment tax credit for solar power"). Combined PV ecoroof systems can be a high initial investment 
119

120

121

122

123

124

125

126

127

128

129

130

131

132

133

134

135

136

137

138

monetarily and environmentally, but if the design is optimized and the initial costs can be paid, the long-term return and reward are high.

\subsubsection{Environmental Cost}

There can be an initially high environmental cost of installing a new PV-green roof system. Lamnatou studied the overall environmental impact and costs of combined PV-green roof systems in 2015, using the ReCiPe method, which ultimately looks at the damage to human health, the ecosystem, and resource availability in the long-term (Lamnatou et al. 2015a). The research focused on systems in Spain, despite mixed conclusions, Lamnatou found that the PV system had a high initial impact, but combining it with a green roof reduced the impact longterm due to the high performance from the cooling effects of the green roof (Lamnatou et al. 2015a). Initial impacts can be mitigated by buying locally when possible and using sustainably sourced materials when possible in the PV construction.

\subsubsection{Application}

Not all buildings have the load capacity on the roof to support a green roof and/ or PV system (green roofs are typically the heavier of the two). The City of Portland's Stormwater Management Manual says when installing an ecoroof, "The load-bearing capacity of the roof must be evaluated by a licensed professional, and the design must comply with building code requirements.” p.106 (“Stormwater Management Manual”). Having combined systems installed may not be feasible for residential houses and older commercial buildings.

\subsubsection{Space Required}

The space required to have both a green roof and a PV system could be competitive, in Hui's article there was a stated concern that in using both technologies, they are competing for 
141 available roof space (Hui et al. 2011). However, in Lamnatou and Chemisana's 2015 article, they

142 praise the combined system for having a better utilization of space compared to using each

143 system separately (Lamnatou et al. 2015b). It may be up to design and location to determine if

144 the combined system is saving space as opposed to each competing for space.

145 Some of the benefits include increased energy output from the solar panels, while the panels may

146 potentially protect the green roofs from harsh sun, reduced heat island effects in urban areas, and

147 improved water management. Cons associated are an initial cost barrier, initial steep

148 environmental impacts from the PV system, not being applicable for all roofs, and spacing. In the

149 long-term, the combined system is an excellent method for saving costs and improving the urban 150 environment.

\section{$151 \quad$ 3.0 Thesis Question}

152 How do photovoltaic cells on greens roofs impact soil moisture in Portland, Oregon, across

153 seasons? To address this question, this research evaluates the effects of shading and rain shadow 154 on the moisture levels behind the panels compared to the moisture levels in front of the panels.

\section{$155 \quad$ 4.0 Hypothesis}

156 It is predicted that the moisture level underneath the PV cells will differ from the moisture level

157 in front of the cells. The PV cells may stop rain and water from reaching the soil undeath the

158 panels, and the sunshade may affect the evapotranspiration of the soil moisture when there is 159 substantial sunlight.

\subsection{Why this Work is Needed}

161 Multiple PV-green roof research papers reference the benefit to the green roof having a PV

162 module on it, without direct research to support the claim of the specifics of how it improves the 
163 green roof. Frequently in research papers, the benefit of not having direct light on the vegetation

164 is mentioned, but less on how the soil hydrology changes with the addition of solar panels, which

165 can affect the plants. The information about how shade and moisture affect the green roof in the

166 combined system can be used to alter the setup of future systems for optimization and maximum

167 benefit.

\section{$168 \quad 6.0$ Material and Methods}

169 This section will review the set of the combined system testbeds and how data will be collected.

\section{$170 \quad$ 6.1 Experimental setup:}

171 Data used in this research was collected from PV panels and green roof test beds on the Science

172 Research and Teaching Center (SRTC) Building at Portland State University (PSU), Portland,

173 Oregon. There are four testbeds, each with four SolarWorld 175-Watt photovoltaic panel (see

174 Figures 1 and 2). The dimensions of each PV panel are $0.8 \mathrm{~m}$ by $1.6 \mathrm{~m}$; all are south-facing.

175 Panels are spaced 0.3m apart. Each panel has an Enhance M210 Microinverter with a maximum

176 power output of 210 watts. Each test bed is approximately $3.8 \mathrm{~m}$ by $4.7 \mathrm{~m}$. In each corner, there

177 is a drain plug (See Figure 4). The setup is had $16 \mathrm{~cm}$ of soil cover, a root barrier, and a water-

178 resistant membrane. The two primary plants used in the green roofs are Sedum Album and

179 Sedum Floriferum (see Figure 2). The sedum was chosen for their previous successful use in

180 green roofs, their shallow root system, and their resiliency. In the summertime the green roofs

181 were irrigated using a spray irrigation system with sprayers located in each corner of each bed. 


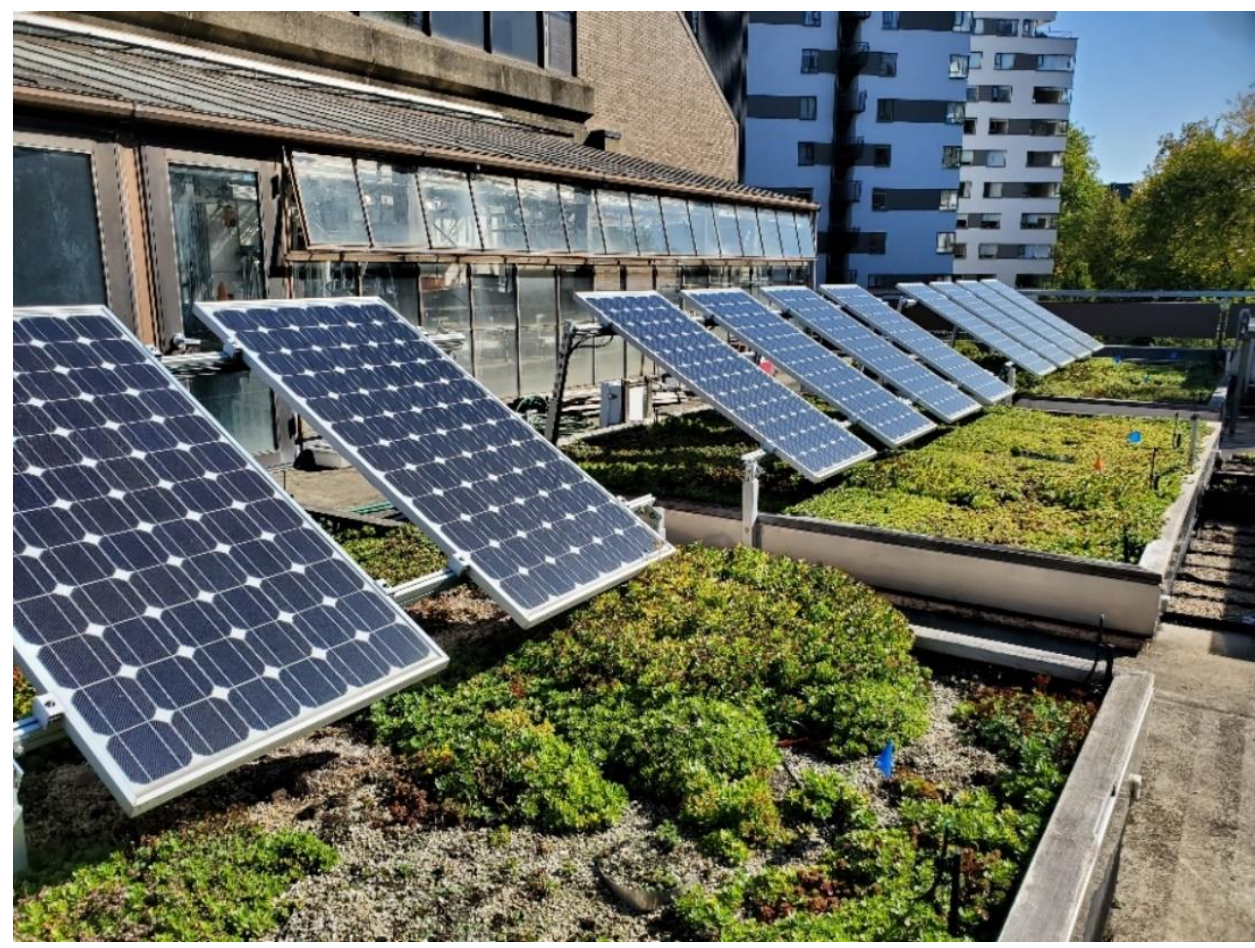

183 Figure 1. PSU STRC PV-Green Roof Experimental Setup's Front (Looking South East)

184

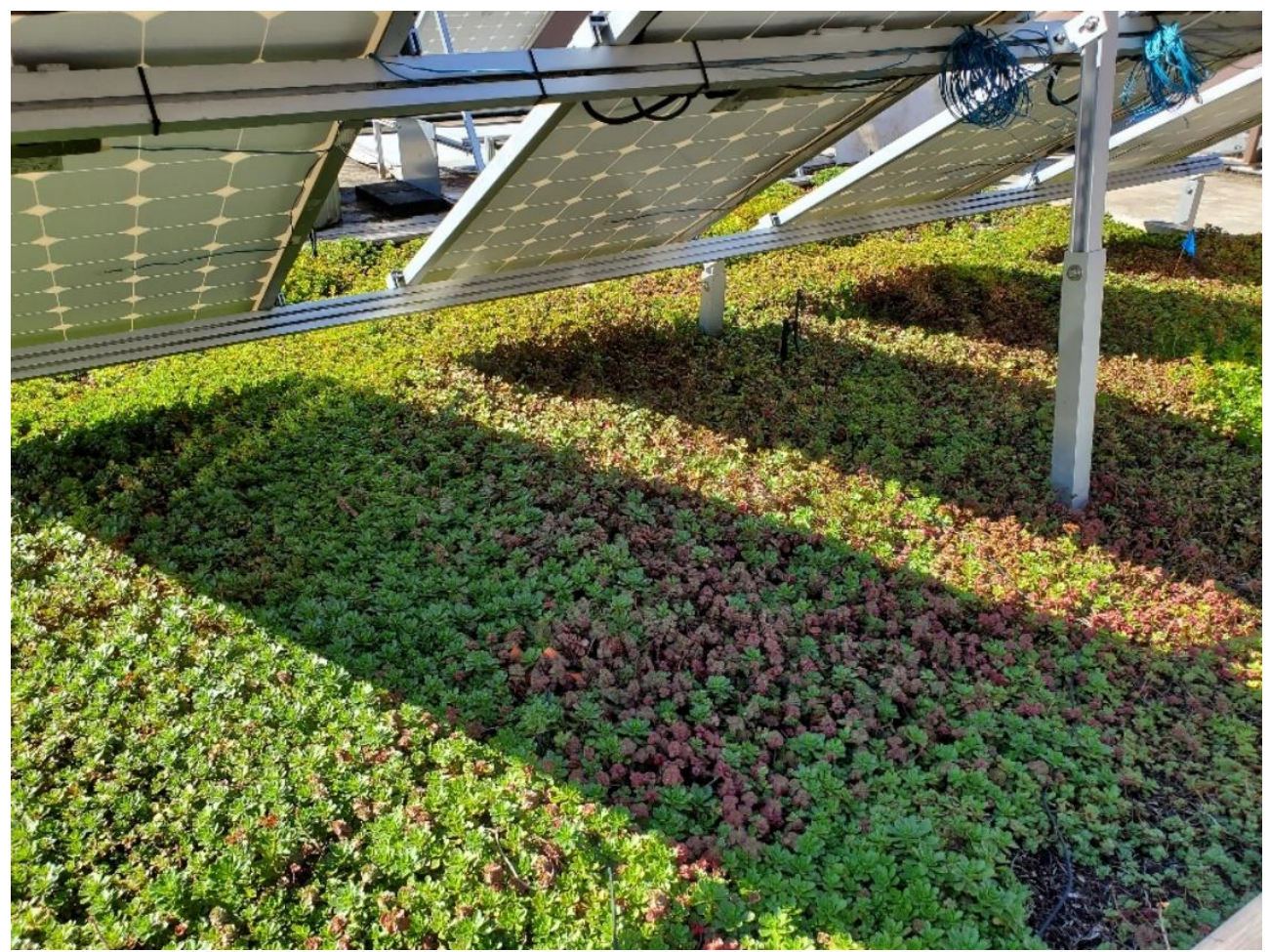

186 Figure 2. PSU STRC PV-Green Roof Experimental Setup from Behind (Looking Southwest)

\subsection{Collection of Moisture Data:}


A soil moisture sensor collected moisture data (Decagon EC-5, see Figure 7). The moisture sensor reports the percentage of moisture. These sensors determine moisture content based on dielectric permittivity of the material, there was a $2.5 \mathrm{~cm}$ sensing radius (Figure 7). The sensor data was then correlated to volumetric moisture data. The moisture data was recorded every minute for a year and stored by a data logger (Campbell scientific, CR1000, see Figure 6). The moisture data set was condensed and averaged out by the day. There were four dielectric-based soil moisture sensors in each quadrant of each PV-green roof testbed (see Figure 5).

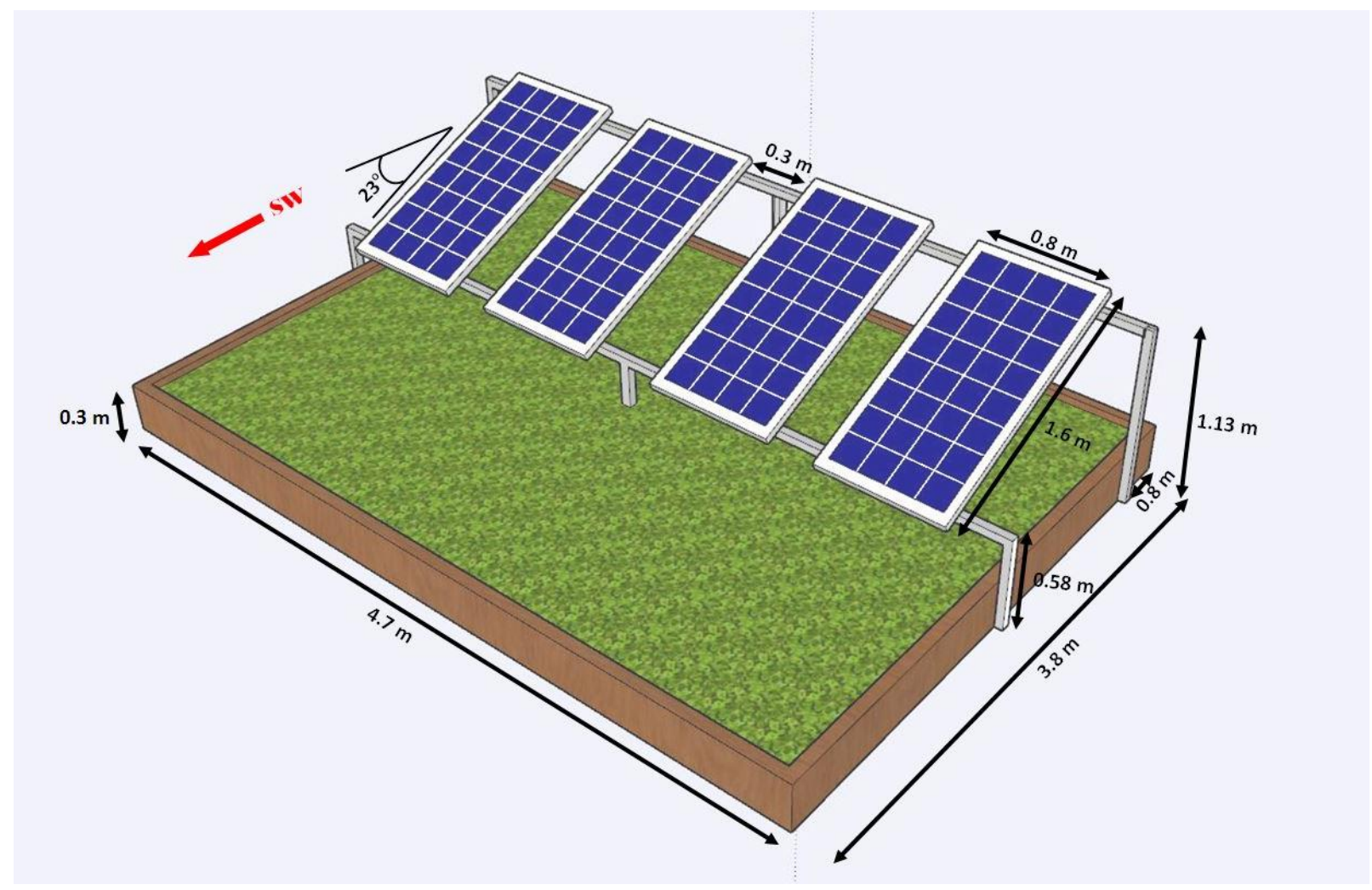

Figure 3. Dimensions of PV-Green Roof Test bed 


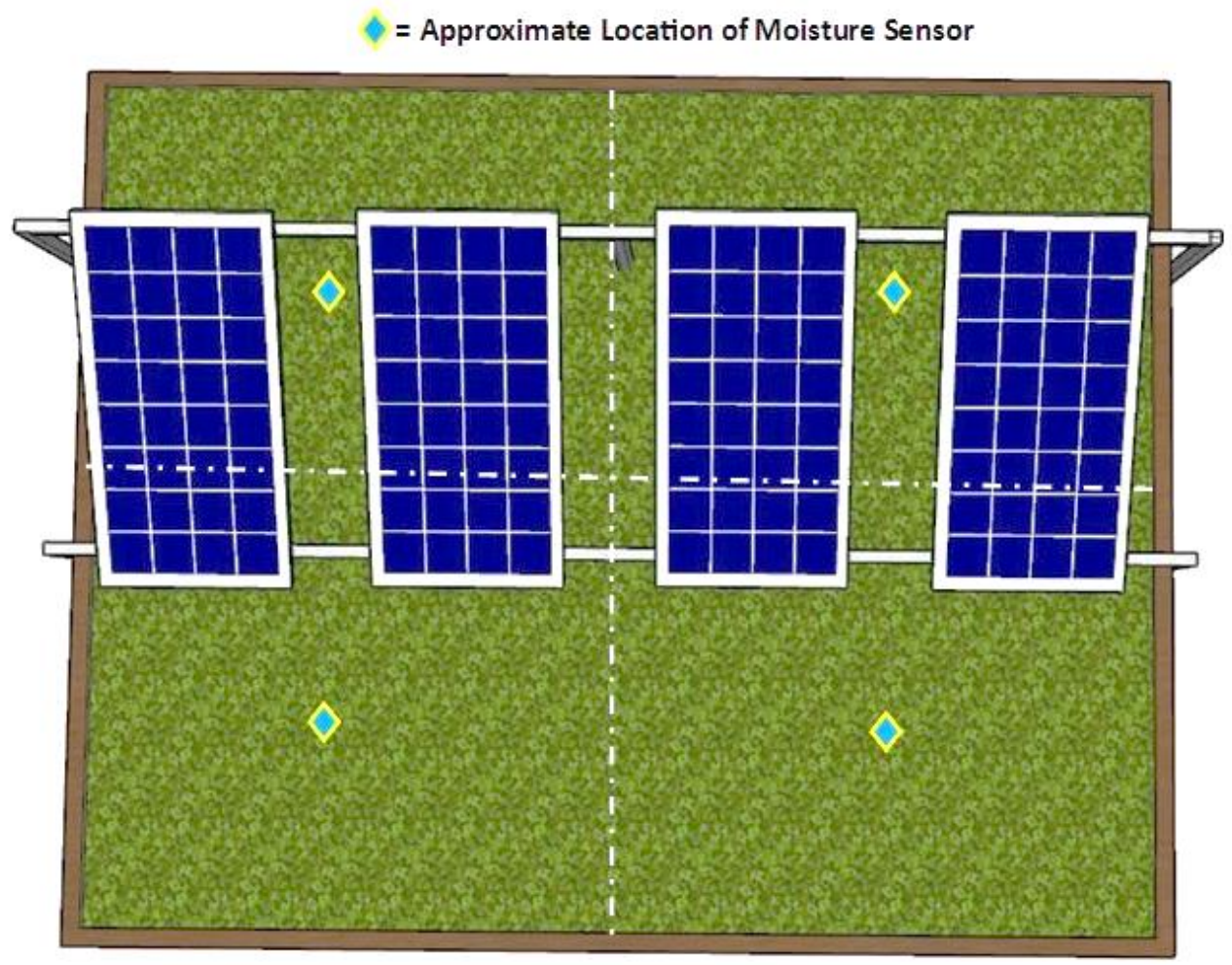

198

199 Figure 4. Approximate Sensor Locations

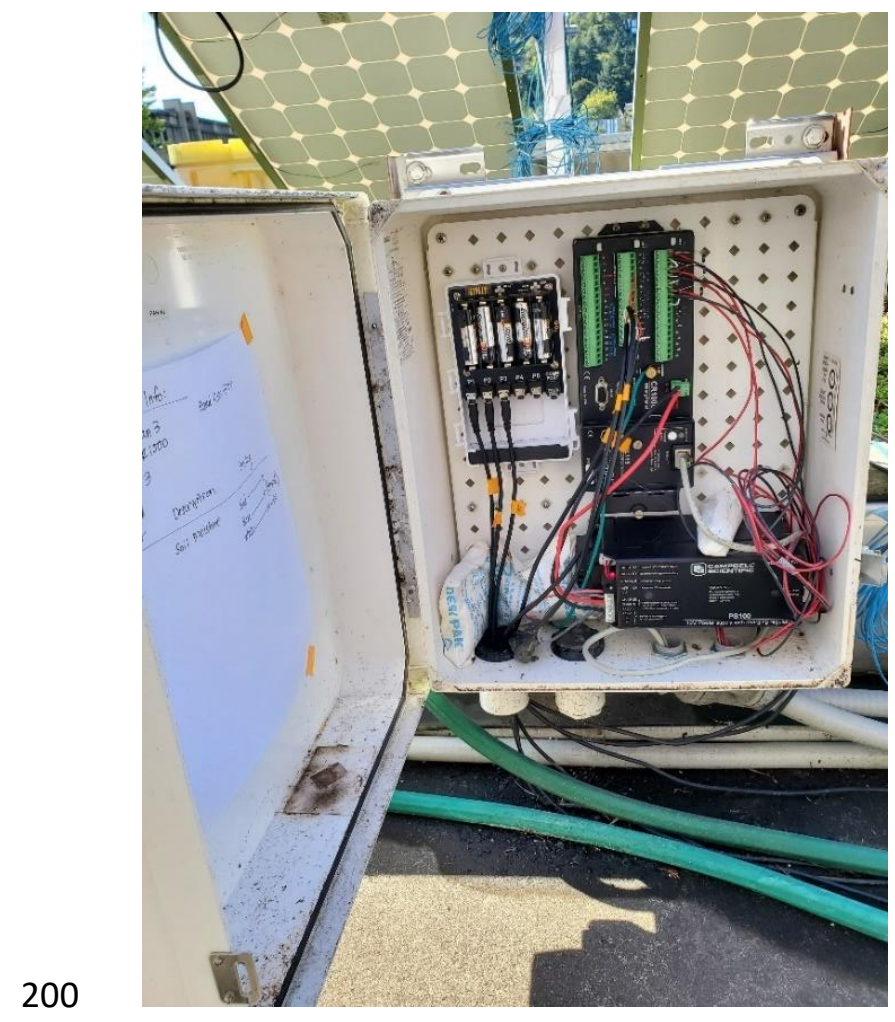

201 Figure 5. Data Collection Box 


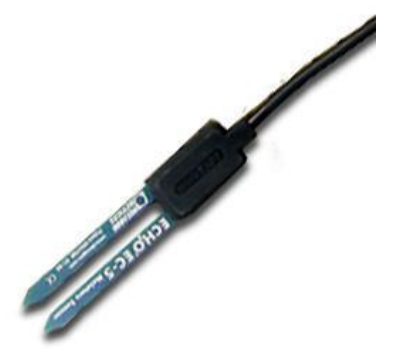

202

203

204

205

206

207

208

209

210

211

212

213

214 Google Sketchup has a feature for the position of the sun at different times of the day, year, and

215 at specific time zones (Portland is GMT-7). The simplified experiment set up was modeled, and

216

217 through three dates from sunrise to sunset. The pictures of each panel for a day were layered at

218 eighty percent transparency over one another in Microsoft Publisher to create a combined image.

219 The combined image shows areas that received the most amount of sunlight in the brighter areas

220 and the least in the darkest areas of the picture. The PV Cells face south-west, a google map

221 image of Portland was imported to Google Sketchup, and the model was placed directly on top 
222 of where their placement was on the map to ensure accuracy with solar direction. A second story

223 behind the panels could have created potential additional shading, so the section of the building

224 directly behind the panels was modeled for accuracy (See Figure 8). An example of what the

225 model looks like before modeling at 100\% opacity can be seen in Figure 9.

226 Using the model, a rain shadow area will also be estimated. A rain shadow is when there is no

227 rain hitting a section of sedum because the PV Cells will be blocking it. The rain shadow

228 estimation will be made by drawing lines directly down from each corner of the PV Cells. The

229 wind would change the area of a rain shadow, but since this is not a water model, that effect will

230 not be taken into consideration.

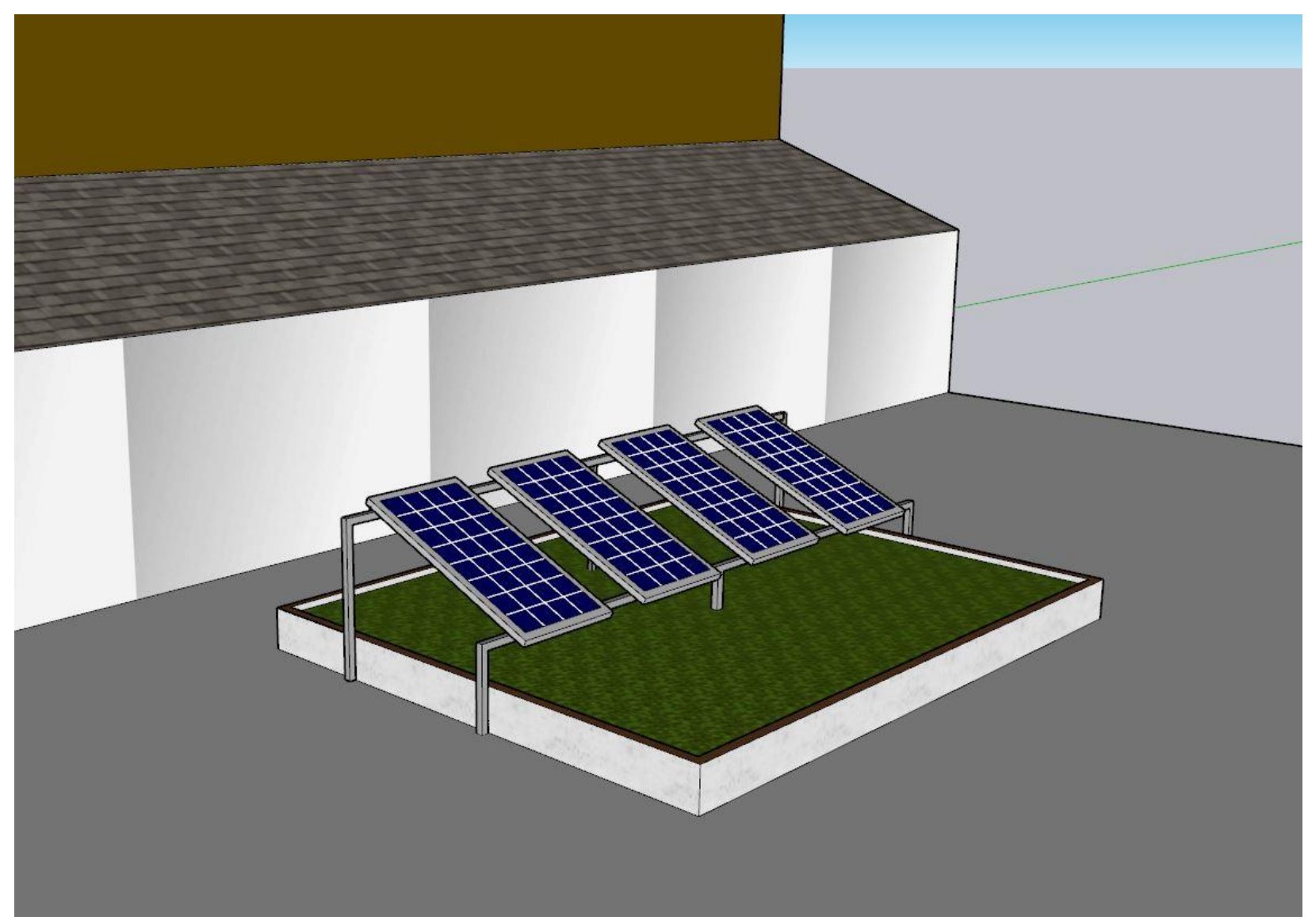

232 Figure 7. Shading Model Set-up 


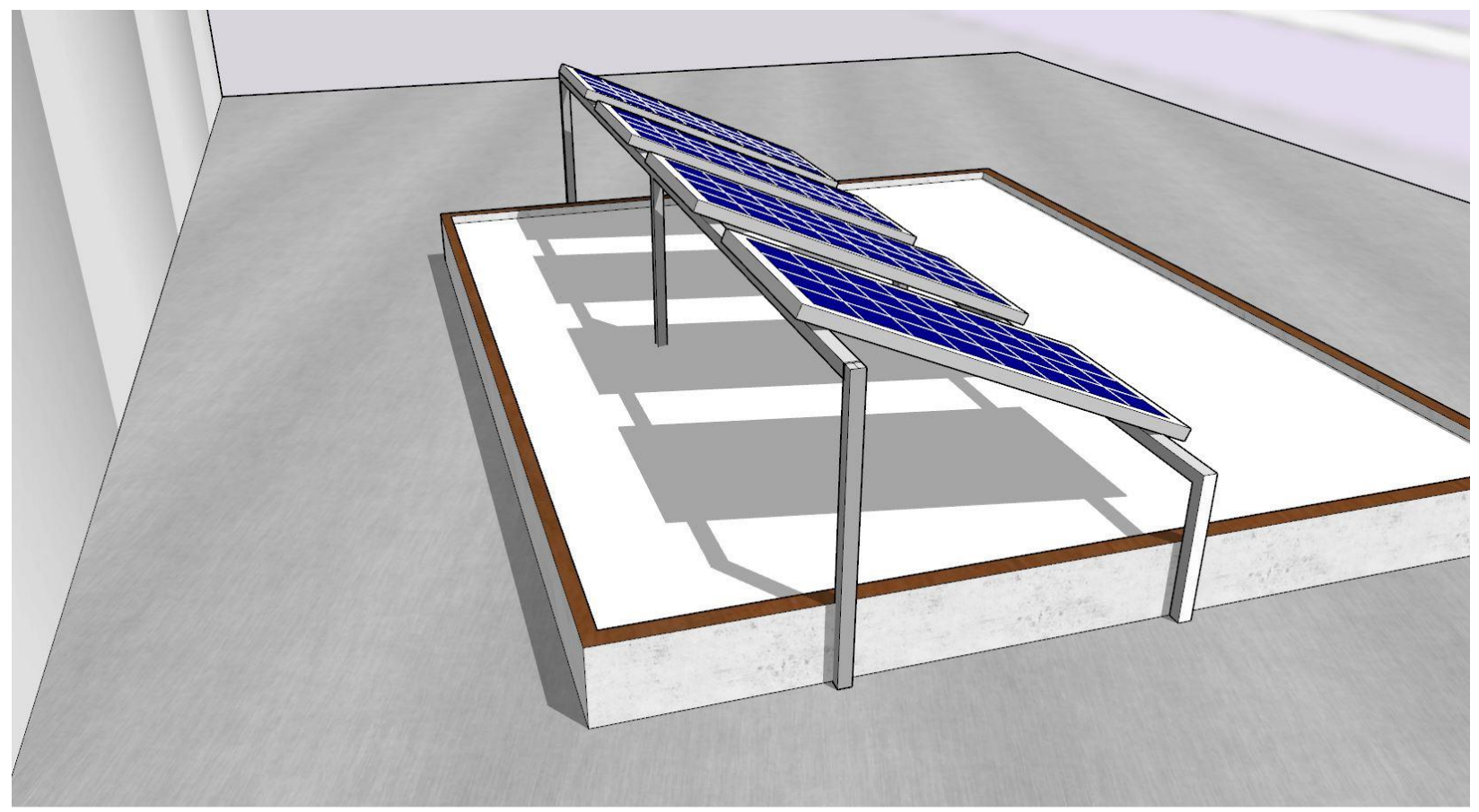

Figure 8. The Shadows on the Model without Layering

The analysis of soil moisture and information on the testbeds is still being conducted as of August 28, 2020.

\subsection{Effects of Combined Systems to Consider}

The following considers different aspects that affect the performance of combined PV-green roof systems. Understanding the possible effects is essential for comprehending the parameters of this research. Discourse about green roofs requires local adjustments, such as tilt angle, for example, since how the sun is captured differs in different latitudes and longitudes in the world. For example, the optimal tilt angle for Hong Kong or Spain might not be ideal for the Pacific Northwest. Plant type will vary based on the yearly weather of the location as well.

\subsection{Plant Type}

Plant types for green roofs vary widely and significantly affect the overall success and resiliency of the roof. For the sake of this paper, only sedum green roofs will be observed, although roofs 
247 with other types of vegetation are commonplace. Butler found that the sedum helped reduce

248 water loss from the soil and the fact that sedum, such as Sedum album has a shallow root system,

249 and high growth makes it a perfect candidate for green roofs (Butler et al. 2011). Each species of

250 sedum has differences in growth rate, drought tolerance, leaf shape, and root depth (Butler et al.

251 2011). Sedum Album, Sedum Rupestre, Sedum Sexangulare, and Sedum Spurium are commonly

252 used on green roofs, but the small differences can create changes in overall performance. An

253 experiment in the research of a PV-sedum roof versus a PV-gazania roof showed that the sedum

254 roof led to $2.21 \%$ more efficiency than the gazania attributed to the higher irradiance received on

255 the PV cells with the Sedum (Lamnatou et al. 2015b). Schroll's experiment theorized that the

256 plant selection would primarily affect the retention of water during storm and dry weather events

257 (Schroll et al. 2011). Having a verity of plant species could potentially maximize benefits green

258 roofs provide.

\section{$259 \quad 7.2$ Substrate}

260 Substrate is the material that vegetation is planted in. The substrate for an ecoroof is placed

261 above a waterproof membrane and root barrier. According to the City of Portland's Stormwater

262 Manual, a growing medium minimum of 4 inches is required (Schroll et al. 2011). Water holding

263 capacity should be a consideration to capitalize on stormwater retention (Schroll et al. 2011).

264 Jahanfar discussed sections where water cumulates, such as in front of the solar panels, where

265 small temporary pools can be created (Jahanfar et al. 2018). Lamnatou's analysis of PV-green

266 roof research mentions that a thicker soil substrate leads to a higher reduction of heat fluctuations

267 from the building, and soil that is less dense can have good insulator effects as well, which can

268 leave to money saved with reduced heating and cooling (Lamnatou et al. 2015b). 
270 When setting up the PV system, there are many factors to take into account; some are the tilt or 271 angle at which the solar panels are facing the sun, the spacing in between each panel, and the

272 placement height off the roof. Jahanfar analyzed the shading effects of PV-green roof combined

273 systems by observing plant growth at two different heights of $0.6 \mathrm{~m}$ and $1.2 \mathrm{~m}$ (Jahanfar et al.

274 2018). The research found that the native forbs and grasses' growth was $47 \%$ greater with the 1.2

275 m modulus, but they noted that when the modulus is up that high, there is not the cooling effect

276 that makes the combined system optimal (Jahanfar et al. 2018). Statler's research was explicitly

277 designed to find an optimum tilt angle in Portland, OR, and was found to be $36^{\circ}$ (Statler 2017).

278 The article also pointed out many of the PV systems in Portland are more than $10^{\circ}$ off from the

279 proposed optimal angle (Statler 2017). For panels that are in areas with a significant seasonal

280 difference, the optimal tilt angles range from $18^{\circ}$ in the summer and $69^{\circ}$ in winter (Statler 2017).

281 One concern that was not found in the articles was the spacing in between each solar panel. Light

282 filters in between the panels, which may affect the growth and health of the plants behind the 283 panels.

$284 \quad$ 7.4 Plant Protection: Moisture Level/ Shading

285 Several articles suggest that having PV panels on green roofs may be beneficial to the plants

286 because of the shading, but none of them analyzed this effect quantitively, just qualitatively. The

287 Ecoroof standard for the City of Portland states, "Solar panels and ecoroofs are compatible with

288 each other. Solar panels provide shade for the plants and protect them in inclement weather. The

289 ecoroof helps cool the solar panels. Solar should be installed with breaks between panels to allow

290 rainwater and light to reach the plants.” (p.1) (“Central City 2035 - Ecoroof Standard”).

291 Chemisana states that "The modules protect the plants from high irradiances." (p.256)

292 (Chemisana et al. 2014). Lamnatou in the 2015 article states that "PVs protect plants from direct 
293 exposure to sunlight and in this way plant growth and plant species variety are enhanced."

294 (p.270) (Lamnatou et al. 2015b). Note that Lamnatou references the Chemisana article,

295 Photovoltaic-Green Roofs: An Experimental Evaluation of System Performance when citing this

296 claim, but that article does not have any citations or research for their claim.

297 Witmer's 2011 article mentions, "PVs benefit from the thermal properties of the green roof while

298 the green roof simultaneously benefits by reduced scorching from the partial shading of the

299 array." (p.3) (Witmer et al. 2011). The main research article that does not wholly agree is

300 Jahanfar's, who theorized the reason for the better plant growth with the taller panels is because

301 there was better solar radiation and rain exposure (Jahanfar et al. 2018). Jahanfar did not use

302 sedum and did not quantitively conduct additional research to prove this theory. Sedum Album,

303 which was used in this research, prefers full sun but can tolerate light shade ("Sedum Album

304 Care.”).

$305 \quad 8.0$ Results

306 These results came from data analyzed and collected between October $18^{\text {th }}, 2018$, to September

$30710^{\text {th }}, 2019$. First, the moisture data results will be analyzed, followed by the shading effect

308 analysis of the panels using the Google Sketchup model.

\section{8.1 Moisture Data Results:}

310 The refined data took the averages of each day to correspond to the National Oceanic and

311 Atmosphere Association's (NOAA) and the National Centers for Environmental Information

312 (NCEI) Portland Airport precipitation data, which was daily ("National Centers for

313 Environmental Information"). Outlier data was removed when it was outside twice the standard

314 deviation. Only two data points were removed. To analyze the effects of moisture of the soil in

315 regard to the PV Cells, the front moisture level of each pan was averaged, and the back moisture 
316 level of each pan was averaged (See Graph 1). Three distinct patterns emerged from the overall

317 graph where were categorized by three different seasons. A rainy season from October $18^{\text {th, }} 2018$

318 to April $18^{\text {th, }}$ 2019, where there was constant rainfall, and the front and back moisture levels

319 followed similarly (See Graph 2). The transitional season was from April $19^{\text {th }}, 2019$ to June $18^{\text {th }}$,

3202019 (See Graph 3). It was during the transitional season that the graph started to diverge, with

321 the emergence of dry periods, but the pans were also not irrigated at this time. Finally, a dry

322 season occurred from June $19^{\text {th }}, 2019$ to September $10^{\text {th }}, 2019$, which was mainly in the summer

323 and occurred when the pans were being irrigated regularly.

324 Irrigation needed to be identified in the data set. The pans were irrigated, but the exact dates of

325 irrigation were not part of the original data set. Irrigation was found by identifying when there

326 was a jump in moisture but not precipitation, which occurred starting on June $19^{\text {th }}, 2019$. The

327 irrigation following the Jun $19^{\text {th }}$ date was found out to be weekly, approximately until August $8^{\text {th }}$,

328 2019, when it seemed that irrigation was stopped.
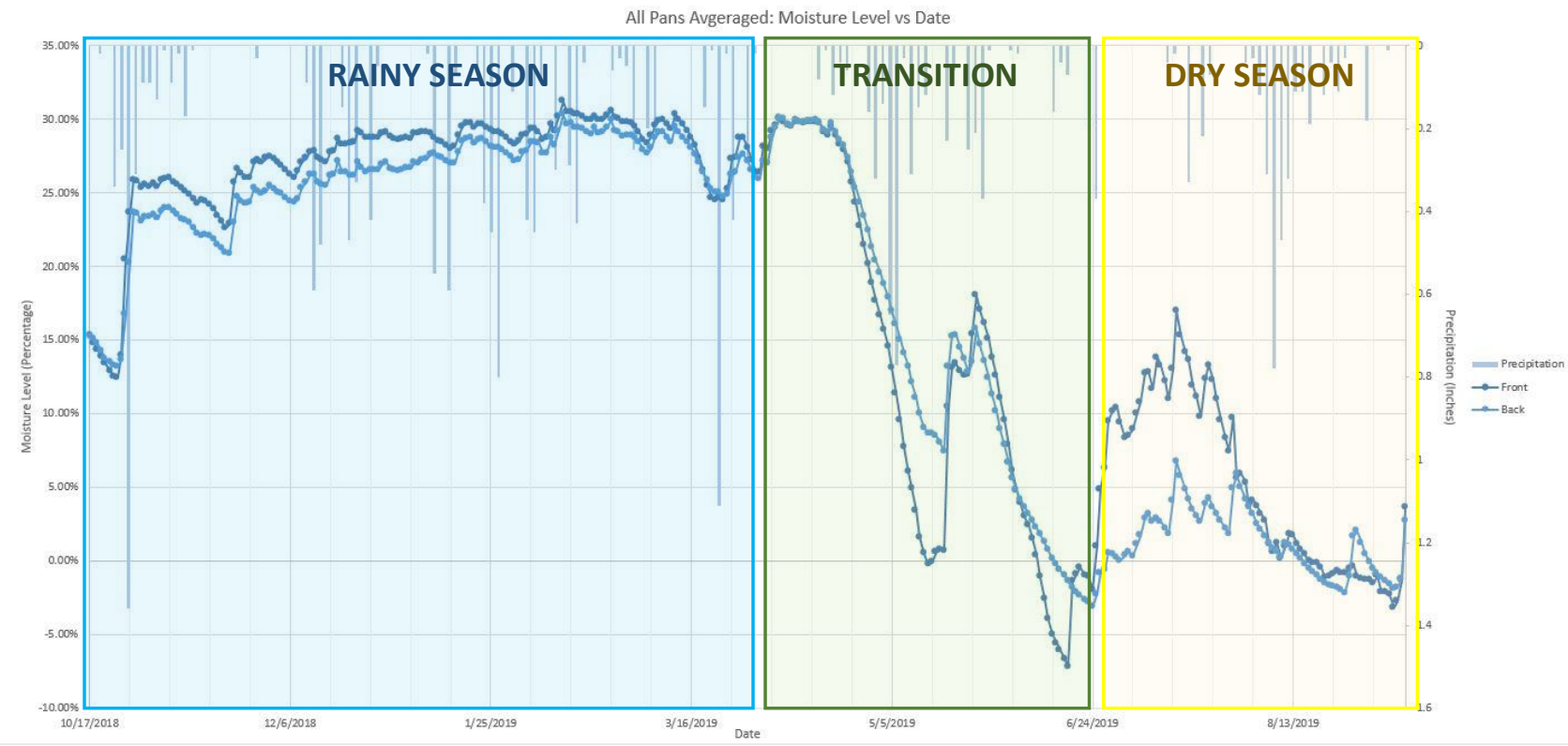

330 Graph 1. All Pans Averaged: Moisture Level vs. Date 
331 During the rainy season, displayed in the above figure, the front of the pan has a slightly higher

332 moisture level than the back of the pan (See graph 2). In Graph 2, the two lines of data of the

333 front and back moisture levels are consistent with each other. The majority of the standard error

334 bars for the moisture level overlap, suggesting that the difference in moisture levels from the

335 front of the pans to the back is nearly insignificant. When comparing Graph 6 through Graphs 8,

336 it can be seen that graphs 5 and 7 show a higher moisture level in front of the pans, while Graphs

3376 and 8 show high moisture levels in the back of the pans. Generally, the data shows moisture

338 levels increasing with rainfall events and decreasing during dry periods.

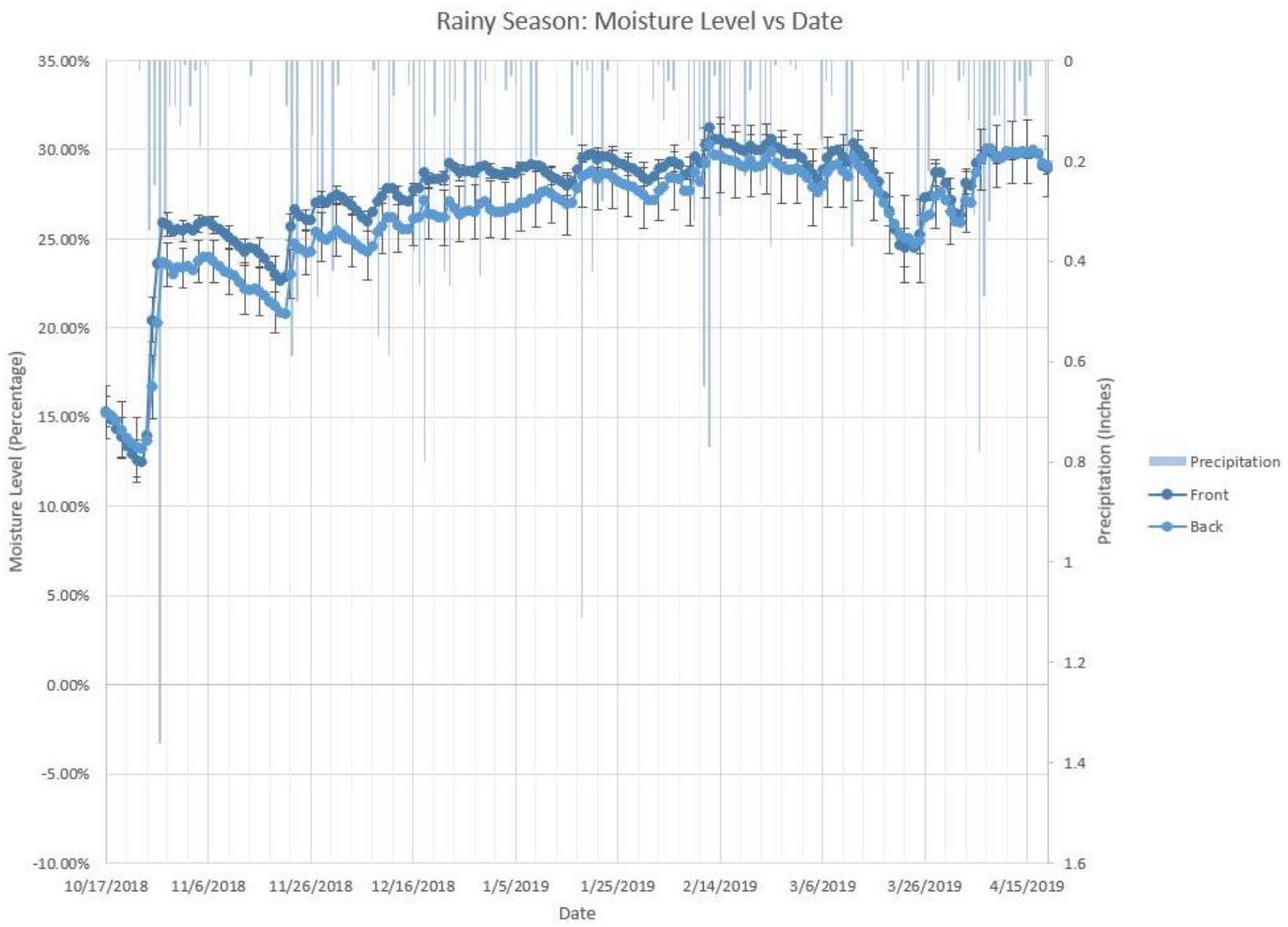

Graph 2. Rainy Season: Moisture Level vs. Date

341 In Graph 3, there are very few of the standard error bars which overlap during the transition

342 period. Note that in Graph 3, the back sensors had a higher moisture percentage. The one point 
343 where there was a switch back to the front sensors having a higher moisture level was after a 344 major rainfall event starting on May $24^{\text {th }}, 2019$, with the back sensors regaining the higher 345 moisture level on June $6^{\text {th }}, 2019$.

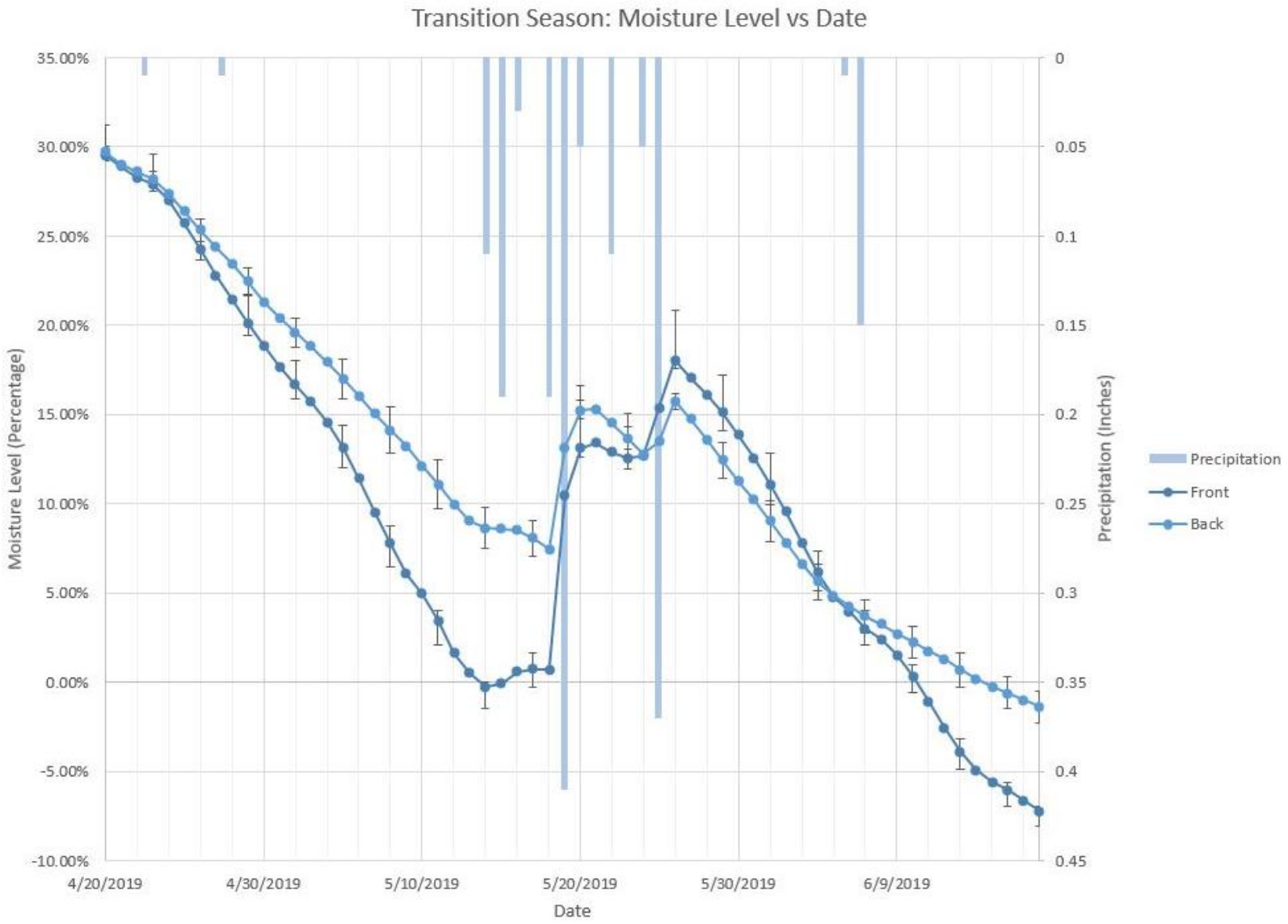

347 Graph 3. Transition Season: Moisture Level vs. Date

348 Finally, the dry season data shown by Graph 4 displays the summer and early fall months where 349 it was the driest and when the pans were irrigated. Moisture level jumps in Graph 4, where no 350 precipitation is present, are most likely due to spray irrigation that happened approximately once 351 a week. When looking at Graphs 6 and 7 in the same time period, there were more sporadic 352 jumps in the front sensors compared to the back. From June $19^{\text {th }}, 2019$ to August $28^{\text {th }}, 2019$, the 353 front sensors displayed a significantly higher moisture percentage. After the $28^{\text {th, }}$ the sensors at 354 the back of the panels display a higher moisture percentage again. When looking at the moisture 
355 percentages trend of having the percent rise when there is no rainfall event stops on August $12^{\text {th }}$, 3562019 , indicating that this was most likely when irrigation stopped as well.

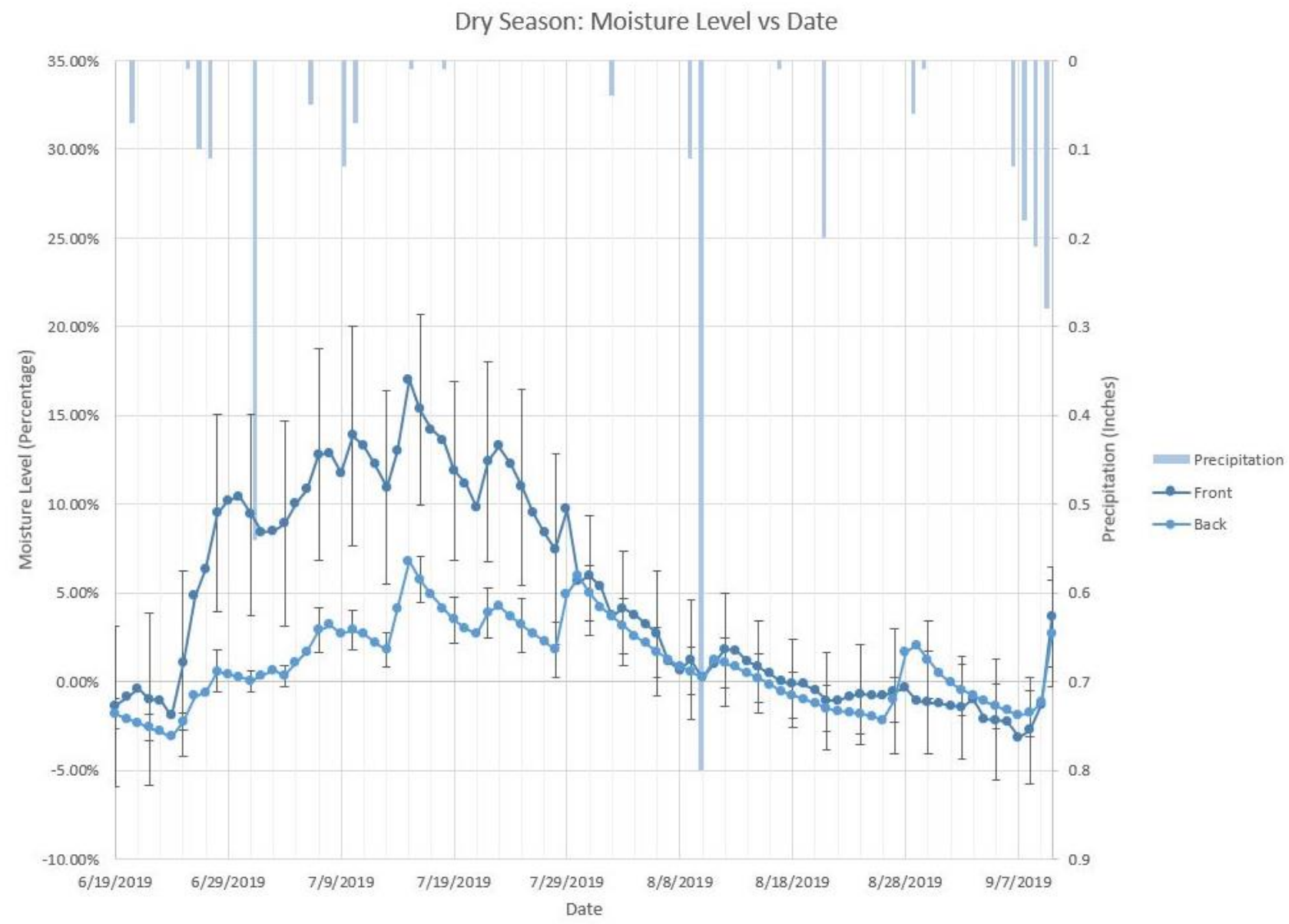

357

358 Graph 4. Dry Season: Moisture level vs. Date

359

360

361

362 


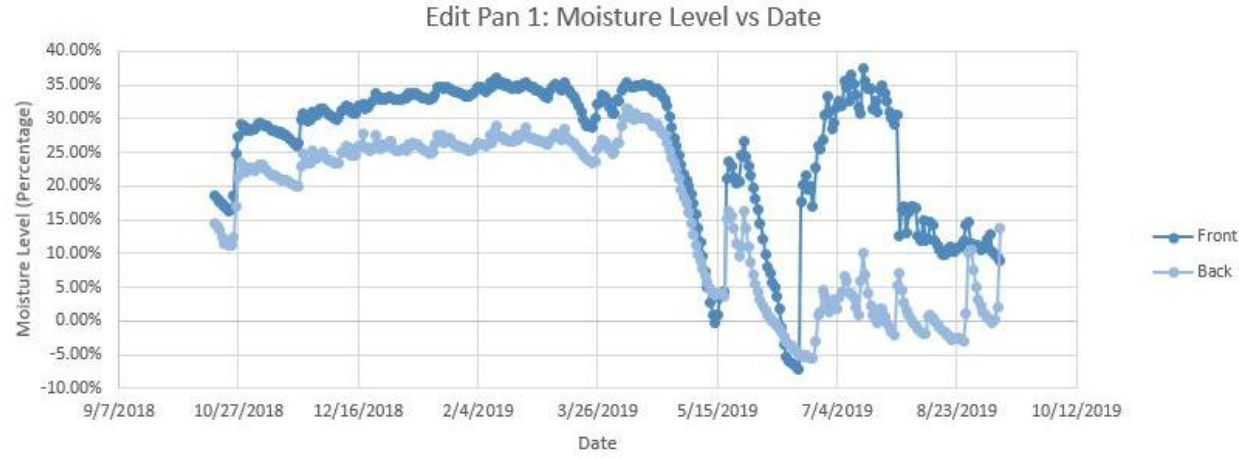

364 Graph 5. Pan 1: Moisture level vs. Date

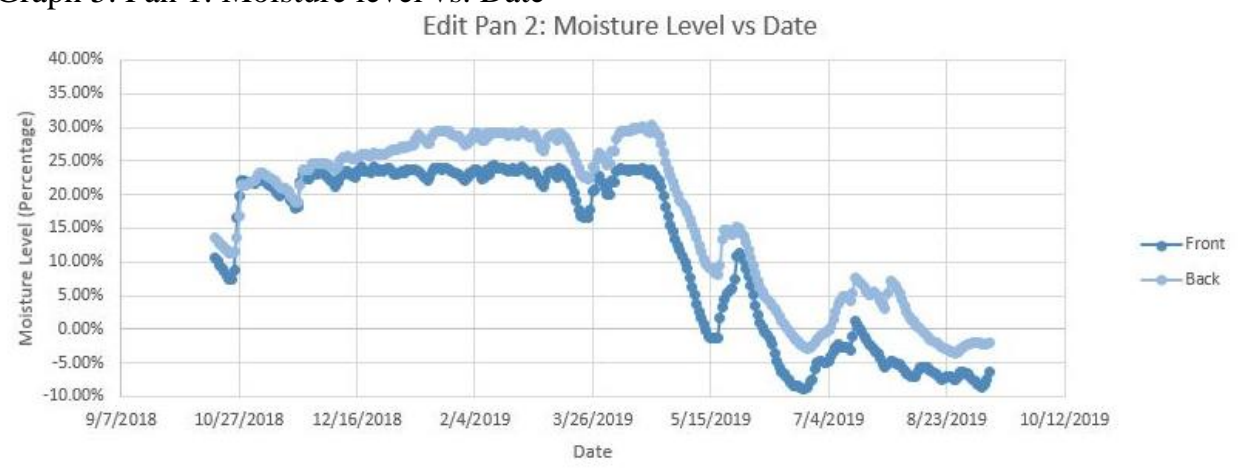

Graph 6. Pan 2: Moisture level vs. Date

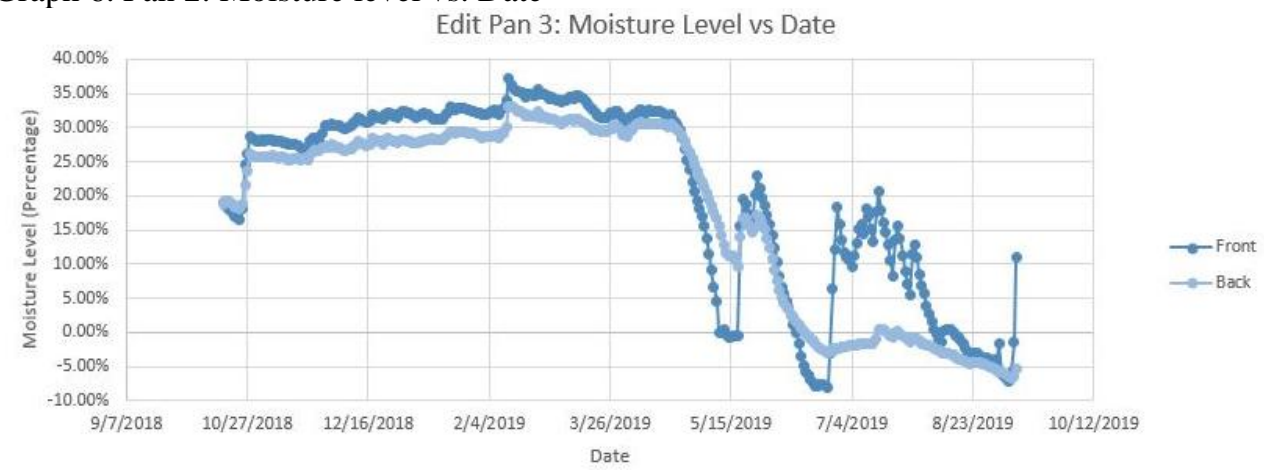

368 Graph 7. Pan 3: Moisture level vs. Date

369

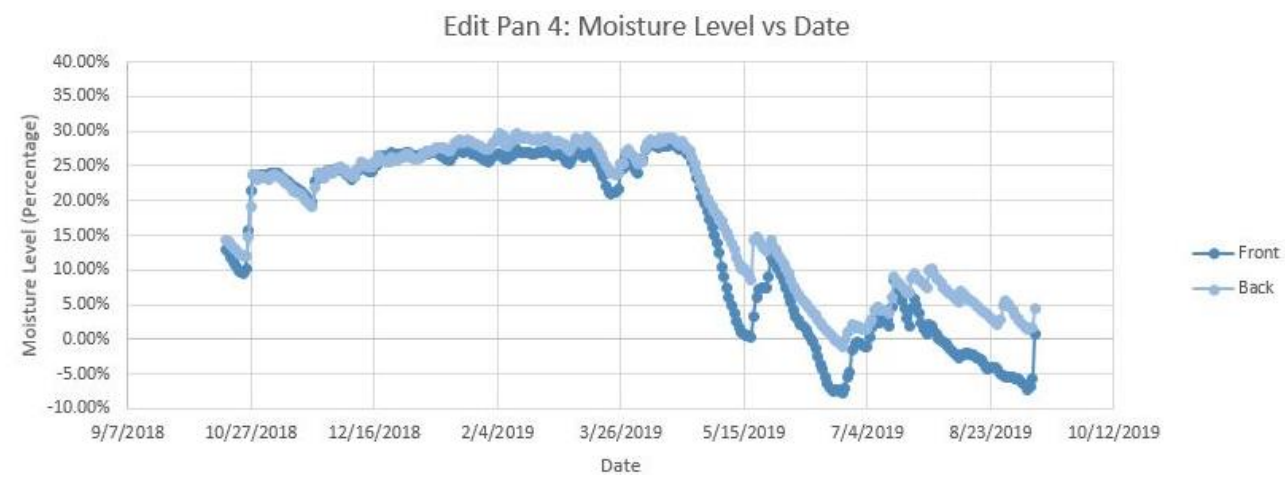

371 Graph 8. Pan 4: Moisture level vs. Date 


\subsection{Shading Effect Modeling Results:}

373 The dates chosen for the sunshade modeling were taken in the middle of the rainy, transition, and

374 dry season. Three pictures were created as results from the eighty percent transparency

375 overlapping. Figure 10 is from January 16th, Figure 11 is from May 19th, 2019, from 6:00 a.m.

376 to 8:00 p.m., and Figure 12 is from July 30th, 2019, from 6:00 a.m. to 8:00 p.m. The sedum

377 section of the testbed was colored white to display the shadows more clearly. The overall area

378 the shadows appeared on the pan are highlighted by a red box. January's figure had fewer

379 sunlight hours overall and was darker in general (See Figure 10). The section of the box covered

380 with a shadow is at the very back of the pan, with the section under the front of the solar panel

381 receiving a decent amount of sunlight.

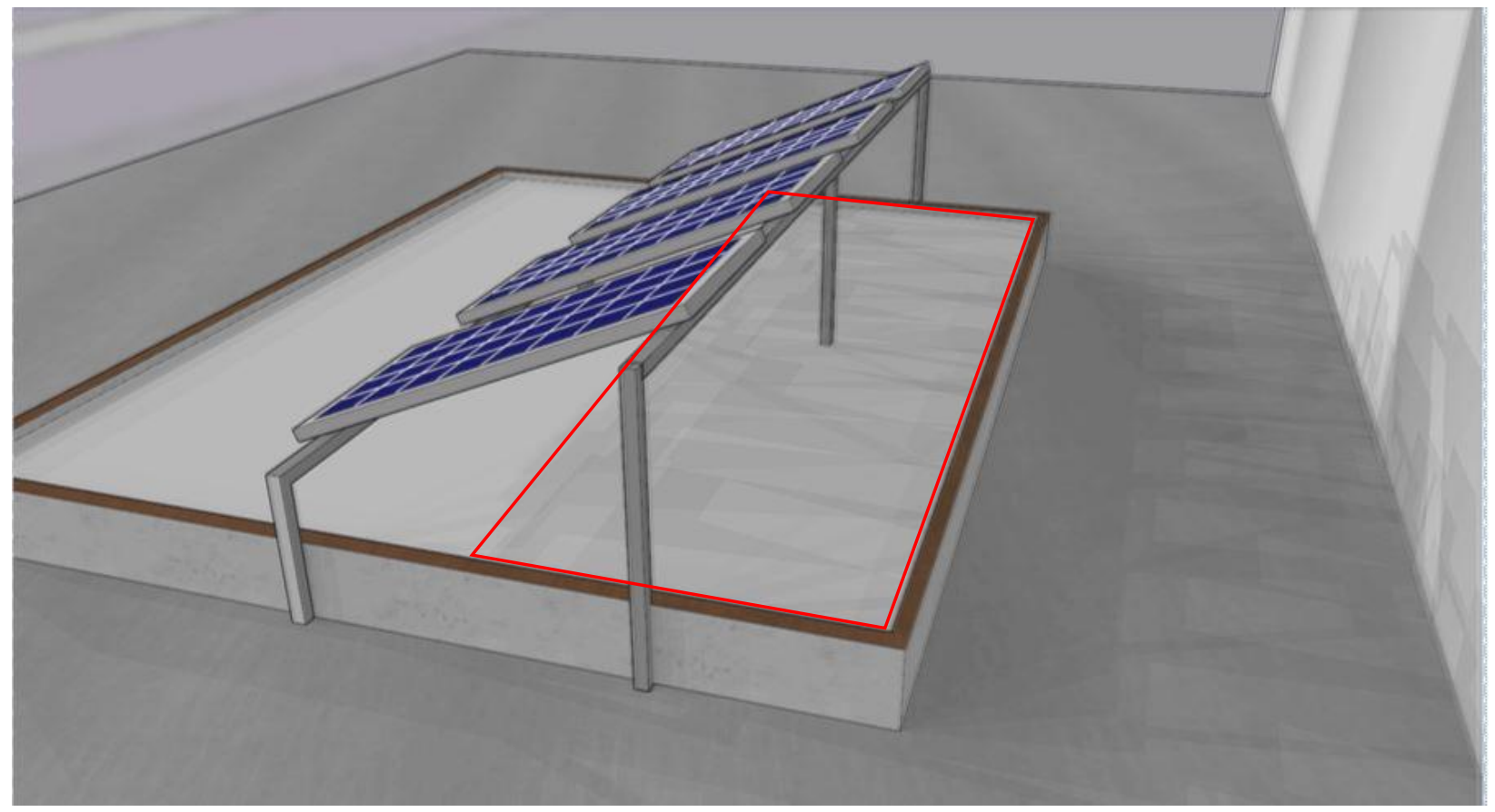

Figure 10. Shading Effects Rainy Season 1/16/2019 9 a.m. to 6 p.m.

384 The rainy season was the longest period observed in this study. Figures 11 and 12 look very

385 different from Figure 10 with there being a 124-day difference between Figures 10 and 11, but 
386 Figures 11 and 12 had a 73-day difference. That being said, Figures 11 and 12 look similar to 387 each other and will be discussed together. In both figures, the shadow area is moved forward to 388 be closer to the front of the PV Cells with the back of the pan, receiving more sunlight. The 389 overall width of the shadow is slightly more in the spring and summer months. In Figures 10 390 through 12, there are complex lighter and darker areas of the overall shadow, meaning that 391 different areas underneath the panel do not receive the same amount of sunlight throughout the 392 day or year because of the changing position of the sun and the width of the panel slits.

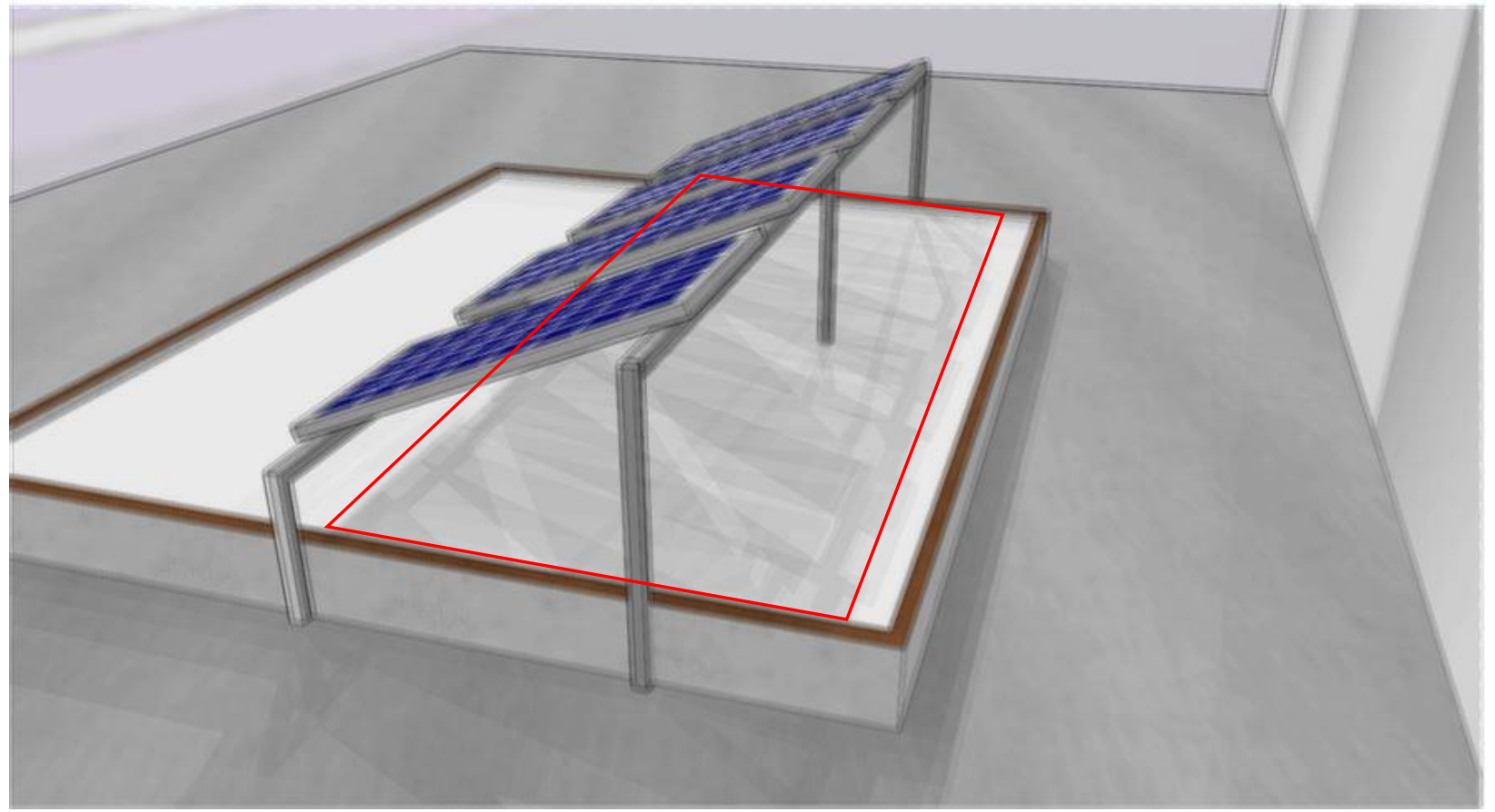

Figure 11. Shading Effects Transitional Season 5/19/2019 6 a.m. to 8 p.m. 


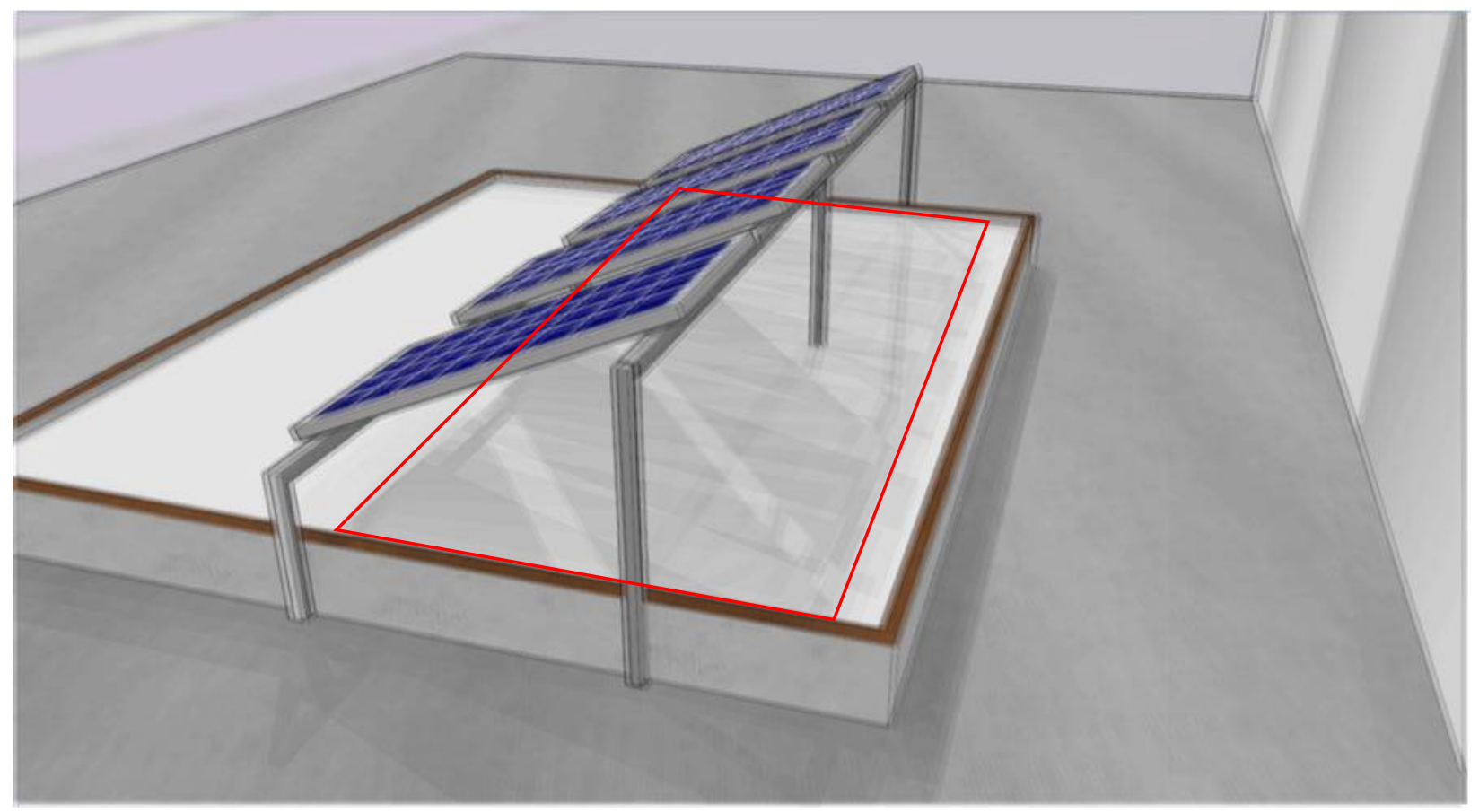

Figure 12. Shading Effects Dry Season 7/30/2019 6 a.m. to 8 p.m.

398 An elementary rain shadow was created in Googled Sketchup and can be seen in Figure 13. The

399 grey section of the model underneath the PV Cells is the approximate area that would be affected

400 by a rain shadow. The grey area would potentially receive less rainfall and thus soil moisture

401 because the PV Cells would be covering the ground. The light blue area in the model displays

402 what areas would receive an average amount of rainfall. The dark turquoise section of the model

403 displays a rough estimate of the section of the pan that would receive extra water because the

404 rain that falls on the solar panels would, in theory, run down the panels, which created a small

405 pooling effect at the base. Because this is just a physical model and not a water simulation, the

406 areas are not exact. 


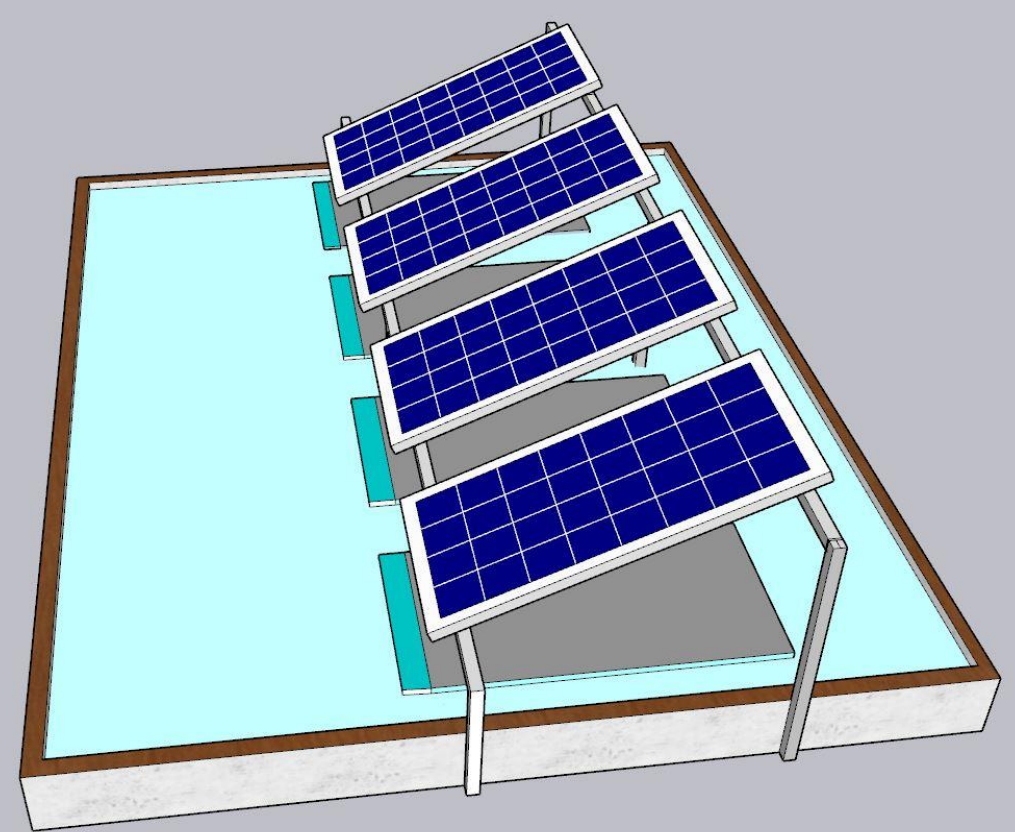

Figure 13. Potential Rain Shadow

\subsection{Discussion}

410 The overall effects of the PV-ecoroof green system and substrate moisture levels, errors that

411 could have come throughout the experiment, the potential rain and shad shadow for the rainy,

412 transitional, and dry seasons, and future research is described in this section.

413 Shading through the model did not display large areas that received more shade or light behind

414 the panels. The transitional and dry season showed more defined lines of lighter and darker sun

415 shadows, but overall, there was a general shading behind the panels with the sun light reaching

416 the back throughout the day. The latitudinal and longitudinal location and the south-west facing

417 position were factors and allowed for light to hit the plants behind the panels, but still, receive

418 more shade throughout the day then the plants in the front. Taking into account that shading

419 differences in the front versus the back of the PV cells could potentially help with understanding

420 how to install a more diverse plant selection, because some eco-roof plants may want less direct 
421 exposure of sunlight throughout the day (Lamnatou et al. 2015b). The Ecoroof standard for the

422 City of Portland suggested having panels to allow for water and sunlight to reach plants, having a

423 slit in between the panel placement did allow for water and sunlight to come through, but not

424 evenly (“Central City 2035 - Ecoroof Standard”).

425 The moisture levels changed throughout the seasons, with a rain shadow being the likely culprit.

426 The potential rain shadow area in Figure 13 displays where dry spots may occur because the

427 panel blocks the rainwater. Higher moisture levels in the front of the testbed in Figure 2 could be

428 attributed to this lack of a shadow, but this was when water was most available, and there was at

429 most a 3\% difference from the front and back moisture sensors. Schroll theorized that plant

430 selection would primarily affect the retention of water events (Schroll et al. 2011). The choosing

431 of plants for combined system PV-ecoroofs could be enhanced by understanding this subtle

432 change in moisture levels in front and behind the PV-cells. The moisture level behind the panels

433 seemed to stay moist longer after large rainfall events in the transitional and dry periods when

434 dismissing irrigation. This experiment's spray irrigation system did not seem to each of the

435 sensors, as well as rainfall did. The reason for the back-panel soil keeping moisture longer is

436 potentially because there was less direct exposure to the sun. Ecoroofs are generally designed to

437 require less maintenance and little to no irrigation compared to green roofs, so having soil stay

438 moist for longer periods of time after a rainfall event in Portland, OR, is helpful when designing

439 new installations. Overall having a better understanding of the rain shadow and sunshade is

440 valuable when deciding on plant heterogeneity.

441 There were several potential sources of error that occurred during the experiment. When

442 observing Graphs, 3 to 8 negative moisture percentages were displayed. The moisture sensors

443 were calibrated using previous measurements of soil moisture. The initial calibration of moisture 
444 was too low, resulting in negative moisture percentages in drier weather. Negative $6 \%$ is most

445 likely closer to $0 \%$ moisture, due to it being the lowest percentage observed. Note that even

446 though absolute values for moisture content may be off, the relative differences between the

447 sensors at different locations should still be valid. When observing Graph 3, on 6/6/2019, there

448 was a large rainfall event without an equally high jump in moisture level after the event. The

449 reason for a large precipitation record without a proportional jump in soil moisture could have

450 been because the precipitation data were collected at the weather station at the Portland Airport,

451 which is seven miles away from the project site. Although the rainfall mainly corresponds to the

452 jumps in moisture in the graphs, there is potential for considerable weather changes in that seven

453 miles. The airport could have received much more rain that day than at Portland State's Campus.

454 The other reason for the discrepancy is the Hysteresis effect in soil. Hysteresis is defined as the

455 difference in the relationship between the water content of the soil and the corresponding water

456 potential obtained under the wetting and drying process. The soil was dry for an extended period

457 and thus hardened, which in turn could have reduced its ability to absorb water from the rainfall

458 event. Lastly, when observing the individual pan's graphs (Graph 5 to 8), Pans 1 and 3 (Graphs 5

459 and 7) display large jumps in the front line for the dry season. The jumps in the front panel

460 moisture level start soon after irrigation begins. A reason for the erratic jumps could be because

461 of poor sensor placement, so those four sensors receive more water during the spray irrigation.

462 Looking at moisture levels in front and behind PV Cells should continue to be looked at, but with

463 the following recommended alterations. The experiment should be redone using different slit

464 measurements. Modifying such measurements could help observe any substantial changes. A

465 larger pan should be used with PV Cells behind the front panels as well to determine if the

466 sedum is negatively impacted by the shadows the extended out of the box in this experiment. At 
467 least twice as many moisture sensors are needed in each pan to increase accuracy. Having a drip

468 irrigation system instead of a spray one would be more compliant with the City of Portland's

469 standards and potentially reduce the error experienced in the summer with Graphs 5 and 7. A

470 water model would give a more in-depth understanding of how the water moves, pools, and

471 where the rain shadow is in regard to PV Cells and eco-roofs. The precipitation data should be

472 collected at the site of the panels for more accuracy, or at least in closer proximity than the seven

473 miles in this experiment. Finally, this experiment set up should be reproduced in multiple

474 locations. The microclimate created on top of the PSU STRC means these results thus far only

475 apply to this specific location. For these findings to be generalized more research in the different

476 locations must be done. There are numerous improvements that can be made and different

477 variables to test in this subtopic of combined systems, and the previous recommendations are a

478 start.

479 Combined system green roofs and PV cells have the greatest influence on moisture heterogeneity

480 in the transition and dry period for the irrigated roof. It is likely that unirrigated roofs would see

481 the greatest PV influence on substrate moisture variation in the summer months in Portland.

482 More work is needed to determine how this increase in moisture behind PV cells can be utilized

483 to maximize green roof ecosystem services. Future work also should address this question at

484 multiple locations with different irrigation systems and plants to determine if these findings are

485 applicable on a larger scale. 
488 The climate of Portland is characterized by long periods of rain, short summers, and scarce snow 489 that has an overall natural effect. When there are periods of rain, the soil in the front of the 490 panels displays higher moisture levels. While in the dry periods, the soil behind the panels has a 491 higher moisture level, most likely due to the shadow effects delaying evaporation. The difference 492 between the soil moisture levels in the front and back of the PV Cells are similar. Although not a 493 focus in this study, through surface-level observation, the sedum in the front was at the same 494 density as the back of the panel with similar growth. Overall, the PV Cells did not have a 495 noticeable negative effect of the sedum of the eco-roof, and aside from minor changes with the 496 season and the major irrigation change, the solar panel worked well in the combined system.

497 The benefits of long-term PV-green roof systems are worth the initial investment if feasible.

498 More cities include incentives and building codes to support green roofs, such as Portland.

499 Further research should be done on how to optimize the combined system best. The research 500 around moisture levels at different sections of the green roof is just one possible research topic to 501 better understand and explore. If PV Cells have no negative effect on eco-roofs in a combined 502 system, and in fact, the eco-roof positively benefits the solar panel energy output, then why 503 should the city of Portland standard only allow $40 \%$ of solar on green roofs?

\section{Acknowledgments}

505 This experiment took place on the ancestral lands of the Multnomah, Kathlamet, Clackamas, 506 Bands of Chinook, Cowlitz, Wasco, Tualitin, Molalla, and Kalapuya peoples. The raw data was 507 collected by Olyssa Starry, Ph.D. from Portland State University's Honors College: she was also 508 Brook's mentor throughout her time in the honor college. Sensors were placed by research 
509 assistant Hannah Prather and honors student Nathaneil McDougal. This work was supported by $510 \quad$ NSF grant \# 1605843. 


\section{References}

(2014). Cost Analysis for Portland Ecoroof Incentive, rep., City of Portland Bureau of Environmental Services, Portland, OR, 1-32.

“2016 Stormwater Management Manual.” (2016). 2016 Stormwater Management Manual RSS, The City of Portland Oregon, <https://www.portlandoregon.gov/bes/71127>

Butler, C., and Orians, C. M. (2011). "Sedum cools soil and can improve neighboring plant performance during water deficit on a green roof." Ecological Engineering, 37(11), 17961803.

"Case Study: City of Portland, Oregon Ecoroof Incentive." (2017). Case Study: City of Portland, Oregon Ecoroof Incentive | Adaptation Clearinghouse, Adaption Clearinghouse, $<$ https://www.adaptationclearinghouse.org/resources/case-study-city-of-portland-oregonecoroof-incentive.html>

“CENTRAL CITY 2035 - ECOROOF STANDARD.” (2019). City of Portland Oregon, <https://www.portlandoregon.gov/bds/article/732038>

Chemisana, D., and Lamnatou, C. (2014). "Photovoltaic-green roofs: An experimental evaluation of system performance." Applied Energy, 119, 246-256.

Dinardo, K. (2019). "The Green Revolution Spreading Across Our Rooftops.” The New York Times, <https://www.nytimes.com/2019/10/09/realestate/the-green-roof-revolution.html>

Garrison, N., and Horowitz, C. (2012). Looking Up: How Green Roofs and Cool Roofs Can Reduce Energy Use, Address Climate Change, and Protect Water Resources in Southern California, rep., 1-33.

"Heat Island Effect." (2020). EPA, Environmental Protection Agency, <https://www.epa.gov/heat-islands>

Hui, S., and Chan, S. C. (2011). "Joint Symposium 2011: Integrated Building Design in the New Era of Sustainability, 22 Nov 2011 (Tue), Kowloon Shangri-La Hotel, Hong Kong. 'Integration of green roof and solar photovoltaic systems." Kowloon Shangri-La Hotel, Hong Kong.

"Investment tax credit for solar power." (2020). EnergySage, <https://www.energysage.com/solar/cost-benefit/solar-investment-tax-credit/>

Jahanfar, A., Drake, J., Sleep, B., and Margolis, L. (2018). "Evaluating the shading effect of photovoltaic panels on green roof discharge reduction and plant growth." Journal of Hydrology, 568, 919-928. 
Lamnatou, C., and Chemisana, D. (2014). "A critical analysis of factors affecting photovoltaicgreen roof performance.” Renewable and Sustainable Energy Reviews, 43, 264-280.

Lamnatou, C., and Chemisana, D. (2015). "Evaluation of photovoltaic-green and other roofing systems by means of ReCiPe and multiple life cycle-based environmental indicators." Building and Environment, 93, 376-384.

National Centers for Environmental Information (NCEI). (n.d.). "Portland International Airport, OR US Daily Summaries Station Details." Climate Data Online (CDO), National Climatic Data Center (NCDC), <https://www.ncdc.noaa.gov/cdoweb/datasets/GHCND/stations/GHCND:USW00024229/detail> (Aug. 15, 2020).

Scherba, A., Sailor, D. J., Rosenstiel, T. N., and Wamser, C. C. (2011). "Modeling impacts of roof reflectivity, integrated photovoltaic panels and green roof systems on sensible heat flux into the urban environment." Building and Environment, 46(12), 2542-2551.

Schroll, E., Lambrinos, J., Righetti, T., and Sandrock, D. (2011). "The role of vegetation in regulating stormwater runoff from green roofs in a winter rainfall climate." Ecological Engineering, 37(4), 595-600.

"Sedum Album Care." (n.d.). Plant Care Today, <https://plantcaretoday.com/sedumalbum.html>

Spolek, G. (2008). "Performance monitoring of three ecoroofs in Portland, Oregon." Urban Ecosystems, 11(4), 349-359.

Statler, N. E., Adams, A. M., and Eckmann, T. C. (2017). "Optimizing angles of rooftop photovoltaics, ratios of solar to vegetated roof systems, and economic benefits, in Portland, Oregon, USA.” Environment Systems and Decisions, 37(3), 320-331.

Witmer, L., and Brownson, J. (2011). "An energy balance model of green roof integrated photovoltaics: a detailed energy balance including microclimatic effects." ASES 2011 National Solar Conference, Raleigh, NC.

Yang, J., Yu, Q., and Gong, P. (2008). "Quantifying air pollution removal by green roofs in Chicago.” Atmospheric Environment, 42(31), 7266-7273. 